\title{
Pengaruh Kinerja Sosial Terhadap Profitabilitas pada Bank Syariah
}

\section{The Effect of Social Performance to the Profitability of Islamic Banks}

Himmatul Kholidah*

Department of Business, Faculty of Vocational Studies, Universitas Airlangga, Indonesia

\begin{abstract}
Abstrak
Penelitian ini bertujuan untuk mengetahui pengaruh kinerja sosial terhadap profitabilitas bank syariah. Metode dalam penelitian ini menggunakan pendekatan kuantitatif dengan analisis regresi berganda. Data dalam penelitian ini menggunakan empat variabel, yaitu pembiayaan Mudharabah, Qardh dan Zakat sebagai variabel dependen dan laba bersih sebagai variabel independen. Hasil dari penelitian ini adalah hanya variabel Zakat yang berpengaruh positif signifikan terhadap laba bersih. Pembiayaan Mudharabah-Musyarakah dan Qardh tidak berpengaruh signifikan terhadap laba bersih pada bank umum syariah. Disisi lain Pembiayaan Mudharabah-Musyarakah, Qardh dan Zakat secara simultan memiliki pengaruh signifikan terhadap laba bersih di Bank Umum Syariah.
\end{abstract}

Kata kunci: Kinerja sosial, profitabilitas, bank Syariah

\begin{abstract}
This study aims to investigate the effect of social performance to the profitability of Islamic banks. The research method used is quantitative approach with multiple regression analysis. The data in this research have four variables: Mudharabah-Musyarakah Financing, Qardh Financing and Zakah as dependent variables and Net income as independent variable. The result shows that only zakah has significantly positive effects on the net income, but Mudharabah-Musyarakah and Qardh Financing have insignificant effects on the net income of Islamic commercial bank. On the other hand, Mudharabah-Musyarakah Financing, Qardh Financing and Zakah simultaneously have significant effects on the net income of Islamic commercial bank.
\end{abstract}

Keywords: Sosial performance, profitability, Islamic banking 


\section{Pendahuluan}

UU No. 21 Tahun 2008 menjelaskan tentang perbankan syariah bahwa bank syariah adalah bank yang menjalankan kegiatan usahanya berdasarkan prinsip-prinsip syariah, yaitu prinsip hukum Islam dalam kegiatan perbankan berdasarkan fatwa yang dikeluarkan oleh lembaga yang memiliki kewenangan dalam penetapan fatwa di bidang syariah. Sistem perbankan Islam berbeda dengan sistem perbankan konvensional. Perbedaan tersebut terletak pada perbankan Islam tidak hanya dituntut untuk menghasilkan profit tetapi juga dituntut untuk merealisasikan nilai-nilai syariah pada setiap operasi bisnisnya, diantaranya perbankan Islam bebas bunga.

Bank syariah (Setiawan, 2009) memiliki dua fungsi penting yaitu fungsi bisnis dan juga fungsi sosial. Fungsi dan peran bank syariah (Suharto, dkk, 2003: 24) adalah:

(1) Manajer investasi yang mengelola investasi dana nasabah dengan menggunakan akad mudharabah atau agen investasi; (2) Investor yang menginvestasikan dana yang dimilikinya maupun dana nasabah yang dipercayakan kepadanya dengan menggunakan alat investasi sesuai dengan prinsip syariah dan membagi hasil yang diperoleh sesuai dengan nisbah yang disepakati antara bank dan pemilik dana yang dapat dilihat dari besarnya pembiayaan mudharabah dan musyarakah yang diberikan kepada nasabah; (3) Penyedia jasa keuangan dan lalu lintas pembayaran seperti bank non syariah sepanjang tidak bertentangan dengan prinsip syariah; dan (4) pengemban fungsi sosial berupa pengelolaan dana zakat, infaq, shadaqah serta peminjaman kebajikan (qardhul hasan) sesuai dengan ketentuan yang berlaku.

Antonio (2001: 201-202), bank syariah selain memiliki fungsi sebagai pengelola investasi dan penyedia jasa-jasa keuangan juga memiliki jasa sosial. Konsep perbankan Islam mengharuskan bank syariah melaksanakan jasa sosial, melalui dana kebaikan (qardh), zakat atau dana sosial yang sesuai dengan prinsip-prinsip Islam. Menurut Rivai, dkk (2010:184), bank syariah melalui produk-produknya memiliki dua peran utama, yaitu sebagai badan usaha (tamwil) dan badan sosial (maal). Bank syariah sebagai badan usaha (tamwil), berperan sebagai:

(1) Manajer investasi, bank syariah bertindak sebagai manajer dana investasi dari pemilik dana (shahibul maal) dan disalurkan pada penyaluran produktif sehingga menghasilkan keuntungan yang akan dibagi hasilkan antara bank syariah dan pemilik dana. Pengumpulan dana oleh bank syariah dilakukan dengan prinsip wadiah yad dhamanah (titipan), mudharabah (bagi hasil), dan ijarah (sewa); (2) Investor, dana akan dikelola melalui sektor- sektor yang produkti dan tidak melanggar ketentuan syariah; (3) Penyedia jasa keuangan, jasa keuangan perbankan dilakukan dengan prinsip wakalah (pemberian), kafalah (bank garansi), hiwalah (pengalihan utang), dll.

Bank syariah sebagai badan sosial (maal), merupakan bank syariah berfungsi sebagai pengelola dana sosial untuk penghimpunan dan penyaluran dana zakat, infaq, sedekah dan waqaf (ZISWAF) serta penyaluran dana kebajikan (qardhul hasan). Pada UU No. 21 Pasal 4 Tahun 2008 tentang perbankan syariah, menyebutkan bahwa bank syariah juga menjalankan fungsi sosial dalam bentuk baitul maal yang menerima dana yang berasal dari zakat, infaq, sedekah, hibah atau dana sosial lainnya dan menyalurkan kepada organisasi pengelola zakat.

Berdasarkan uraian diatas dapat ditarik benang merah bahwa tujuan dan fungsi dari bank syariah tidak hanya tentang fungsi bisnis tetapi kehadiran bank syariah juga memiliki fungsi sosial. Fungsi sosial ini diharapkan dapat mendorong pertumbuhan dan pemerataan ekonomi agar dana tidak hanya berputar pada beberapa kalangan saja. Menurut Almilia dan Wijayanto (2007) perusahaan yang memiliki kinerja sosial yang bagus akan direspon positif oleh investor, begitu juga dengan sebaliknya.

Penelitian ini bertujuan untuk mengetahui ada tidaknya pengaruh yang signifikan dari kinerja sosial yang dilakukan perbankan syariah terhadap profitabilitas bank syariah. Profitabilitas merupakan kemampuan perusahaan dalam menghasilkan laba dari penjualan barang atau jasa yang diproduksi (Astuti, 2004: 36). Angka profitabilitas antara lain adalah angka laba sebelum dan sesudah pajak, laba investasi, pendapatan per saham, laba bersih dan laba penjualan. Profitabilitas bank syariah dari penelitian ini diperoleh dari laba bersih yang diperoleh bank syariah. Kinerja sosial yang dilakukan oleh bank syariah diteliti melalui:

- $\quad$ Pembiayaan mudharabah-musyarakah pada bank syariah. Menurut Ryandono (2010), pembiayaan yang berbasis bagi hasil dan berprinsipkan kebaikan dapat meningkatkan 
pemberdayaan ekonomi masyarakat dan dapat meningkatkan kesejahteraan masyarakat. Apabila kesejahteraan masyarakat meningkat maka akan meningkatkan dana masyarakat yang dihimpun oleh bank syariah dan dapat meningkatkan pembiayaan yang disalurkan oleh bank syariah. Penyaluran dana yang dilakukan oleh bank syariah dapat menghasilkan manfaat bagi nasabah dan bank syariah, yaitu berupa bagi hasil yang telah disepakati. Hal ini menunjukkan bahwa semakin besar dana yang disalurkan bank syariah kepada masyarakah maka dapat meningkatkan pendapatan dan laba bersih bank syariah.

- $\quad$ Pembiayaan qardh pada bank syariah. Menurut Kurniawan (2010), pembiayaan qardh pada bank syariah mempunyai misi sosial kemasyarakatan, yaitu terdapat sifat saling tolong menolong antara sesama umat yang membutuhkan. Pada sisi komersialnya dapat meningkatkan citra bank dan meningkatkan loyalitas masyarakat terhadap bank syariah, sehingga dapat meningkatkan profitabilitas bank syariah. Hal ini juga dibuktikan pada QS. Al-Baqarah: 245.

"Siapakah yang mau memberikan pinjaman kepada Allah, pinjaman yang baik (menafkahkan hartanya dijalan Allah), maka Allah akan melipatgandakan pembayaran kepadanya dengan lipat ganda yang banyak. Dan Allah menyempitkan dan melapangkan (rezeki) dan kepada-Nya-lah kamu dikembalikan"

Dari ayat diatas dapat disimpulkan bahwa Allah SWT akan memberikan balasan yang berlipat ganda pada seseorang yang memberikan pinjaman kepada orang yang membutuhkan dengan ikhlas dan sesuai dengan prinsip-prinsip Islam.

- Zakat yang disalurkan perbankan syariah. Zakat dapat menumbuhkan perasaan cinta masyarakat terhadap orang yang mengelurkan zakat (Puspitasari, 2014). Melalui kinerja sosial yang baik maka akan tumbuh kepercayaan dan sense of belonging (rasa memiliki) dari masyarakat sehingga masyarakat dapat menyadari bahwa kehadiran perusahaan membawa manfaat dan secara tidak langsung dapat mempengaruhi profitabilitas perusahaan. Hubungan zakat dan profitabilitas bank juga terdapat pada QS. Al-Baqarah: 261.

"Perumpamaan (nafkah yang dikeluarkan oleh) orang-orang yang menafkahkan hartanya di jalan Allah adalah serupa dengan sebutir benih yang menumbuhkan tujuh bulir, pada tiap-tiap bulir seratus biji. Allah melipat gandakan (ganjaran) bagi siapa yang Dia kehendaki. Dan Allah Maha Luas (karunia-Nya) lagi Maha Mengetahui."

Dari ayat diatas dapat disimpulkan bahwa zakat bahwa dengan mengeluarkan zakat, maka Allah SWT akan melipatgandakan harta yang kita punya. Jadi, pengeluaran zakat dapat meningkatkan profitabilitas bank syariah

Berdasarkan uraian diatas maka menarik dilakukan penelitian lebih lanjut mengenai ada tidaknya pengaruh yang signifikan dari kinerja sosial yang dilakukan perbankan syariah terhadap profitabilitas bank syariah.

\section{Riset Question}

Riset Question dari penelitian ini adalah:

- Apakah kinerja sosial bank syariah yang diukur dari pembiayaan mudharabah-musyarakah berpengaruh terhadap profitabilitas bank syariah yang diukur dari laba bersih?

- Apakah kinerja sosial bank syariah yang diukur dari pembiayaan qardh berpengaruh terhadap profitabilitas bank syariah yang diukur dari laba bersih?

- Apakah kinerja sosial bank syariah yang yang diukur dari zakat berpengaruh terhadap profitabilitas bank syariah yang diukur dari laba bersih?

- Apakah kinerja sosial bank syariah (pembiayan mudharabah-musyarakah, pembiayaan qardh dan zakat) secara simultan berpengaruh terhadap profitabilitas bank syariah yang diukur dari laba bersih?

\section{Hipotesis Penelitian}

Berdasarkan riset question, maka hipotesis dalam penelitian ini adalah sebagai berikut: 
- Kinerja sosial bank syariah yang diukur dari pembiayaan mudharabah-musyarakah berpengaruh signifikan terhadap profitabilitas bank syariah yang diukur dari laba bersih.

- Kinerja sosial bank syariah yang diukur dari pembiayaan qardh berpengaruh signifikan terhadap profitabilitas bank syariah yang diukur dari laba bersih.

- $\quad$ Kinerja sosial bank syariah yang yang diukur dari zakat berpengaruh signifikan terhadap profitabilitas bank syariah yang diukur dari laba bersih.

- $\quad$ Kinerja sosial bank syariah (pembiayan mudharabah-musyarakah, pembiayaan qardh dan zakat) secara simultan berpengaruh signifikan terhadap profitabilitas bank syariah yang diukur dari laba bersih.

\section{Metode Penelitian}

Penelitian ini menggunakan pendekatan kuantitatif. Penelitian ini menitik beratkan pada pengujian hipotesis, data yang digunakan harus terukur, dan akan menghasilkan kesimpulan yang dapat digeneralisasikan (Sugiyono, 2012: 10). Pendekatan ini lebih sering berupaya mengukur suatu konsep variabel, sehingga lebih mudah dipahami secara statistik. Menurut Arikunto dalam Anshori dan Iswati (2009:15) penelitian kuantitatif diharuskan menggunakan angka mulai dari pengumpulan data, penafsiran data, serta penampilan hasil penelitiannya oleh karena itu peneliti dituntut memahami dan menguasai statistik sebagai alat analisis data.

\section{Model Analisis}

Model analisis dalam penelitian ini adalah model analisis regresi linier berganda (multiple regression) dengan gambar 1 sebagai berikut:

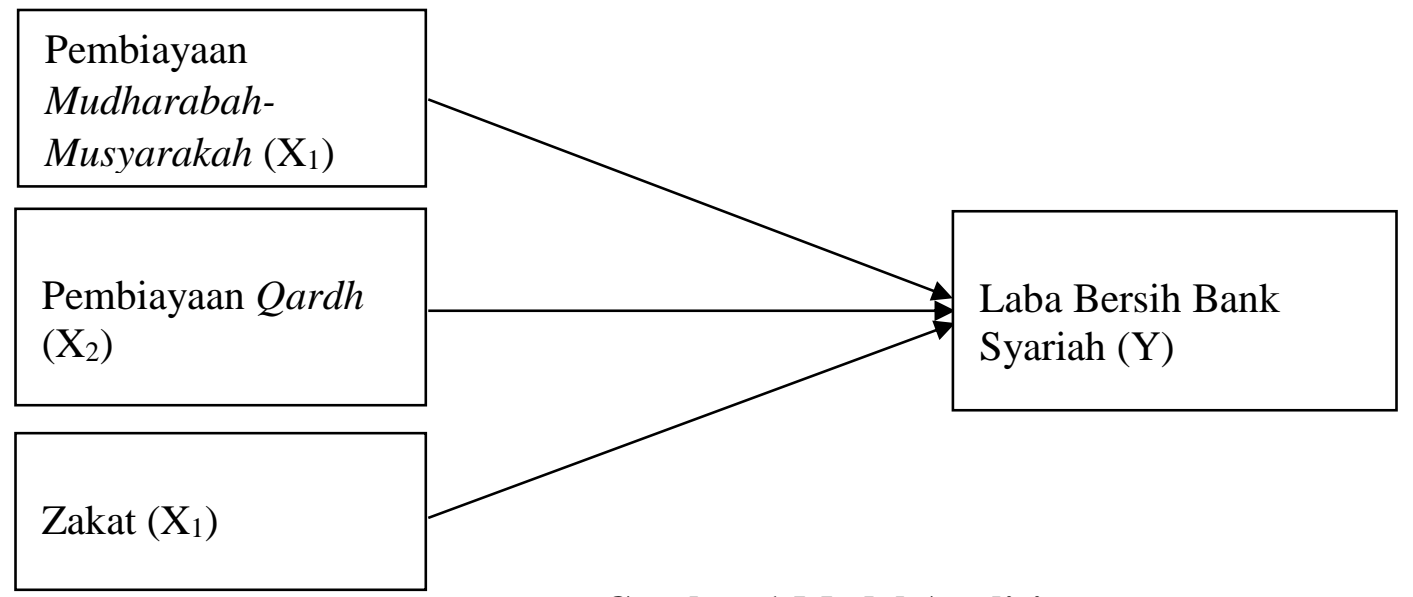

\section{Gambar 1 Model Analisis}

Persamaan regresi linier berganda dalam penelitian ini adalah:

$\mathrm{Y}=\mathrm{a}+\mathrm{b}_{1} \mathrm{X}_{1}+\mathrm{b}_{2} \mathrm{X}_{2}+\mathrm{b}_{3} \mathrm{X}_{3}+\mathrm{e}$

Keterangan:

Y: Laba bersih;

a: Konstanta;

$\mathrm{b}_{1}$ : Koefisien regresi;

$\mathrm{X}_{1}$ : Pembiayaan mudharabah-musyarakah;

$\mathrm{X}_{2}$ : Pembiayaan Qardh;

$\mathrm{X}_{3}$ : Zakat; e: eror.

\section{Definisi Operasional Variabel}

Definisi operasional variabel yang digunakan dalam penelitian ini adalah: 
- Variabel endogen, yaitu laba bersih (Y). Laba bersih dihitung dalam periode 2010-2014 yang terdapat pada laporan keuangan tahunan pada masing-masing bank syariah yang telah dipublikasikan.

- Variabel eksogen, yaitu:

Pembiayaan mudharabah-musyarakah. Pembiayaan mudharabah-musyarakah didapatkan dari total pembiayaan mudharabah dan musyarakah yang dikeluarkan oleh bank syariah pada periode 2010-2014 dan terdapat pada laporan keuangan tahunan pada masing-masing bank syariah yang telah dipublikasikan.

Pembiayaan qardh $\left(\mathrm{X}_{2}\right)$. Pembiayaan qardh didapatkan dari total pembiayaan qardh yang telah dikeluarkan oleh bank syariah pada periode 2010-2014 dan terdapat pada laporan keuangan tahunan pada masing-masing bank syariah yang telah dipublikasikan.

$>$ Zakat $\left(\mathrm{X}_{3}\right)$. Zakat didapatkan dari total dana zakat yang telah disalurkan oleh bank syariah pada periode 2010-2014 dan terdapat pada laporan keuangan tahunan pada masing-masing bank syariah yang telah dipublikasikan.

\section{Populasi dan Sampel}

Populasi dalam penelitian ini adalah Bank Umum Syariah (BUS) yang terdaftar di Bank Indonesia, Bank Umum Syariah yang beroperasi selama tahun 2010-2014, dan Bank Umum Syariah yang mempublikasikan laporan keuangan tahunan pada periode 2010-2014. Penelitian ini menggunakan metode pengambilan sampel secara acak (simple random sampling). Menurut Sugiyono (2012:118), simple random sampling dilakukan secara acak tanpa memperhatikan strata yang terdapat dalam populasi. Sampel dari penelitian ini Bank Muamalat Indonesia (BMI), Bank Syariah Mandiri (BSM), Bank Mega Syariah (BMS), Bank Rakyat Indonesia Syariah (BRIS) dan Bank Negara Indonesia Syariah (BNIS).

\section{Teknik Analisis}

Teknik analisis yang digunakan dalam penelitian ini adalah uji asumsi klasik (uji multikolinearitas, uji autokorelasi, uji heteroskedastisitas, uji normalitas) dan uji hipotesis dengan alat analisis SPSS 16.0.

\section{Analisis dan Pembahasan}

\section{Pembiayaan Mudharabah-Musyarakah Bank Syariah}

Pembiayaan mudharabah-musyarakah diperoleh dari laporan keuangan tahunan yang dipublikasikan pada masing-masing bank syariah pada periode 2010-2014. Tabel 1 menunjukkan bahwa Bank Muamalat Indonesia (BMI), Bank Rakyat Indonesia Syariah (BRIS) dan Bank Bank Negara Indonesia Syariah (BNIS) pembiayaan mudharabah-musyarakah semakin meningkat dari 2010-2014.

Tabel 1. Data Pembiayaan Mudharabah-Musyarakah pada Periode 2010-2014 (dalam Miliar Rupiah)

\begin{tabular}{|c|l|c|c|c|c|c|}
\hline No & \multicolumn{1}{|c|}{ Nama Bank } & $\mathbf{2 0 1 0}$ & $\mathbf{2 0 1 1}$ & $\mathbf{2 0 1 2}$ & $\mathbf{2 0 1 3}$ & $\mathbf{2 0 1 4}$ \\
\hline 1 & Bank Muamalat Indonesia & 7511 & 9915 & 15046 & 21240 & 22066 \\
\hline 2 & Bank Syariah Mandiri & 8395 & 9703 & 10337 & 10752 & 10337 \\
\hline 3 & Bank Mega Syariah & 140 & 73 & 36 & 42 & 40 \\
\hline 4 & BRI Syariah & 1310 & 1760 & 2663 & 4050 & 4977 \\
\hline 5 & BNI Syariah & 1005 & 2326 & 2245 & 2946 & 4443 \\
\hline
\end{tabular}

Sumber: Laporan Keuangan Tahunan, diolah.

Pada Bank Syariah Mandiri (BSM) dan Bank Mega Syariah (BMS) pembiayaan mudharabah-musyarakah mengalami fluktuatif selama periode penelitian. Hal ini menjadi nilai tambah karena pembiayaan mudharabah-musyarakah merupakan pembiayaan yang memiliki risiko yang tinggi dibandingkan dengan akad yang lain, karena tingkat pengembalian yang tidak pasti. 


\section{Pembiayaan Qardh Bank Syariah}

Pembiayaan qardh diperoleh dari laporan keuangan tahunan yang dipublikasikan pada masing-masing bank syariah pada periode 2010-2014.

Tabel 2. Data Pembiayaan Qardh pada Periode 2010-2014

(dalam Miliar Rupiah)

\begin{tabular}{|c|l|c|c|c|c|c|}
\hline No & \multicolumn{1}{|c|}{ Nama Bank } & $\mathbf{2 0 1 0}$ & $\mathbf{2 0 1 1}$ & $\mathbf{2 0 1 2}$ & $\mathbf{2 0 1 3}$ & $\mathbf{2 0 1 4}$ \\
\hline 1 & Bank Muamalat Indonesia & 1196 & 1955 & 1292 & 428 & 144 \\
\hline 2 & Bank Syariah Mandiri & 22356 & 6488 & 6134 & 5.555 & 3584 \\
\hline 3 & Bank Mega Syariah & 66 & 607 & 817 & 261 & 77 \\
\hline 4 & BRI Syariah & 726 & 1957 & 1438 & 960 & 592 \\
\hline 5 & BNI Syariah & 212 & 649 & 643 & 677 & 695 \\
\hline
\end{tabular}

Sumber: Laporan Keuangan Tahunan, diolah.

Tabel 2 menunjukkan bahwa seluruh bank dalam penelitian ini pengeluaran untuk pembiayaan qardh bersifat fluktuatif dari tahun 2010-2014. Menurut Kurniawan (2012) pembiayaan qardh kurang sedikit komersil jika dibandingkan dengan akad pembiayaan lain. Hal ini disebabkan karena pembiayaan qardh diperlukan untuk membantu keuangan nasbah secara tepat dan berjangka pendek, sehingga nasabah al-qardh hanya mengembalikan sejumlah pokok pinjaman dan tidak ada biaya tambahan yang diperjanjikan, kecuali biaya administrasi dan biaya sewa tempat jaminan.

\section{Zakat Bank Syariah}

Jumlah zakat diperoleh dari zakat yang telah disalurkan oleh bank dari laporan keuangan tahunan yang dipublikasikan pada masing-masing bank syariah pada periode 2010-2014. Tabel 3 menunjukkan bahwa Bank Muamalat Indonesia (BMI), Bank Rakyat Indonesia Syariah (BRIS) dan Bank Bank Negara Indonesia Syariah (BNIS) zakat yang dikeluarkan semakin meningkat dari 2010-2014. Pada Bank Syariah Mandiri (BSM) dan Bank Mega Syariah (BMS) zakat yang dikeluarkan mengalami fluktuatif selama periode penelitian. Hal ini perbankan syariah telah melakukan pengeluaran wajib, yaitu dengan berzakat.

Tabel 3. Data Zakat pada Periode 2010-2014 (dalam Miliar Rupiah)

\begin{tabular}{|c|l|c|c|c|c|c|}
\hline No & \multicolumn{1}{|c|}{ Nama Bank } & $\mathbf{2 0 1 0}$ & $\mathbf{2 0 1 1}$ & $\mathbf{2 0 1 2}$ & $\mathbf{2 0 1 3}$ & $\mathbf{2 0 1 4}$ \\
\hline 1 & Bank Muamalat Indonesia & 1 & 4 & 7 & 8 & 12 \\
\hline 2 & Bank Syariah Mandiri & 15 & 19 & 28 & 23 & 3 \\
\hline 3 & Bank Mega Syariah & 2 & 2 & 6 & 5 & 0,6 \\
\hline 4 & BRI Syariah & 0,6 & 2 & 3 & 6 & 7 \\
\hline 5 & BNI Syariah & 0,2 & 1 & 1 & 1 & 3 \\
\hline
\end{tabular}

Sumber: Laporan Keuangan Tahunan, diolah.

\section{Laba Bersih Bank Syariah}

Laba bersih dari bank syariah diperoleh dari laporan keuangan tahunan yang dipublikasikan pada masing-masing bank syariah pada periode 2010-2014.

Tabel 4 Laba Besih pada Periode 2010-2014 (dalam Miliar Rupiah)

\begin{tabular}{|l|l|l|l|l|l|l|}
\hline No & Nama Bank & 2010 & 2011 & 2012 & 2013 & 2014 \\
\hline
\end{tabular}




\begin{tabular}{|c|l|c|c|c|c|c|}
1 & Bank Muamalat Indonesia & 171 & 274 & 389 & 165 & 57 \\
\hline 2 & Bank Syariah Mandiri & 419 & 551 & 806 & 651 & 72 \\
\hline 3 & Bank Mega Syariah & 63 & 54 & 185 & 150 & 17 \\
\hline 4 & BRI Syariah & 11 & 12 & 102 & 130 & 7 \\
\hline 5 & BNI Syariah & 37 & 62 & 50 & 73 & 92 \\
\hline
\end{tabular}

Sumber: Laporan Keuangan Tahunan, diolah.

Tabel 4 menunjukkan bahwa hampir seluruh bank syariah yang diteliti pada periode 20102014 laba bersihnya mengalami penurunan, kecuali pada Bank Negara Indonesia Syariah (BNIS) laba bersihnya meningkat dari tahun 2010-2014.

\section{Uji Asumsi Klasik Regresi}

Sebelum dilakukannya analisis regresi berganda untuk pengujian hipotesis, maka terlebih dahulu dilakukan pengujian keabsahan persamaan regresi berdasarkan asumsi klasik dengan menggunakan program statistical program science (SPSS) 16.0. Hasil pengujian asumsi klasik dijelaskan pada tabel 5.

Tabel 5. Hasil Uji Asumsi Klasik Regresi

\begin{tabular}{|c|c|c|c|}
\hline No & Uji Asumsi Klasik & Penjelasan & Hasil \\
\hline 1 & Normalitas & $\begin{array}{l}\text { Dilakukan dengan menggunakan } \\
\text { tes Kolmogrov-Smirnov. Dasar } \\
\text { keputusan bisa dilakukan } \\
\text { berdasarkan probabilitas (asymp. } \\
\text { sig), yaitu: } \\
\text { 1. Jika signifikansi > } 0.05 \text {, } \\
\text { maka distribusi dari populasi } \\
\text { adalah normal. } \\
\text { 2. Jika signifikansi < } 0.05 \text {, } \\
\text { maka distribusi dari populasi } \\
\text { adalah tidak normal. }\end{array}$ & $\begin{array}{l}\text { Pada uji normalitas dengan } \\
\text { menggunkanan tes Kolmogrov- } \\
\text { Smirnov, tingkat signifkan yang } \\
\text { diperoleh adalah } 0.390 \text { lebih } \\
\text { dari } 0.05 \text {, maka variabel telah } \\
\text { terdistribusi normal. }\end{array}$ \\
\hline 2 & Multikolinieritas & $\begin{array}{l}\text { Uji multikolinieritas dilakukan } \\
\text { untuk mengetahui apakah pada } \\
\text { model regresi yang dihasilkan } \\
\text { ditemukan adanya korelasi antar } \\
\text { variabel eksogen. Tidak terjadi } \\
\text { multikolonieritas antara variabel } \\
\text { eksogen apabila VIF lebih kecil } \\
\text { dari } 10 \text { dan nilai tolerance lebih } \\
\text { dari } 0,1 \text { (Sugiyono, 2011). }\end{array}$ & $\begin{array}{l}\text { Hasil uji multikolinieritas } \\
\text { menunjukkan bahwa nilai VIF } \\
\text { seluruh variabel lebih kecil dari } \\
10 \text { dan nilai tolerance seluruh } \\
\text { variabel lebih besar dari } 0,1 \text {. } \\
\text { Hal ini menunjukkan bahwa } \\
\text { model regresi yang digunakan } \\
\text { tidak terjadi multikolinieritas. }\end{array}$ \\
\hline 3 & Autokorelasi & $\begin{array}{l}\text { Uji Aoutokorelasi dilakukan } \\
\text { untuk mengetahui apakah ada } \\
\text { korelasi antara anggota } \\
\text { serangkaian data observasi. }\end{array}$ & $\begin{array}{l}\text { Hasil uji autokorelasi D-W } \\
\text { menunjukkan nilai } 1,727 \text {. } \\
\text { Model persamaan regresi yang } \\
\text { dihasilkan memperlihatkan } \\
\text { angka D-W berada diantara }-2 \\
\text { sampai }+2 \text {, ini berarti bahwa } \\
\text { model regresi tersebut tidak } \\
\text { terdapat masalah autokorelasi. }\end{array}$ \\
\hline 4 & Heteroskedastisitas & $\begin{array}{l}\text { Uji heteroskedastisitas dilakukan } \\
\text { untuk menganalisa apakah dalam } \\
\text { sebuah model regresi terjadi } \\
\text { ketidaksamaan varian dari suatu }\end{array}$ & $\begin{array}{l}\text { Hasil uji heteroskedastisitas } \\
\text { terdapat titik-titik yang tidak } \\
\text { membentuk suatu pola yang } \\
\text { teratur dan menyebar secara }\end{array}$ \\
\hline
\end{tabular}




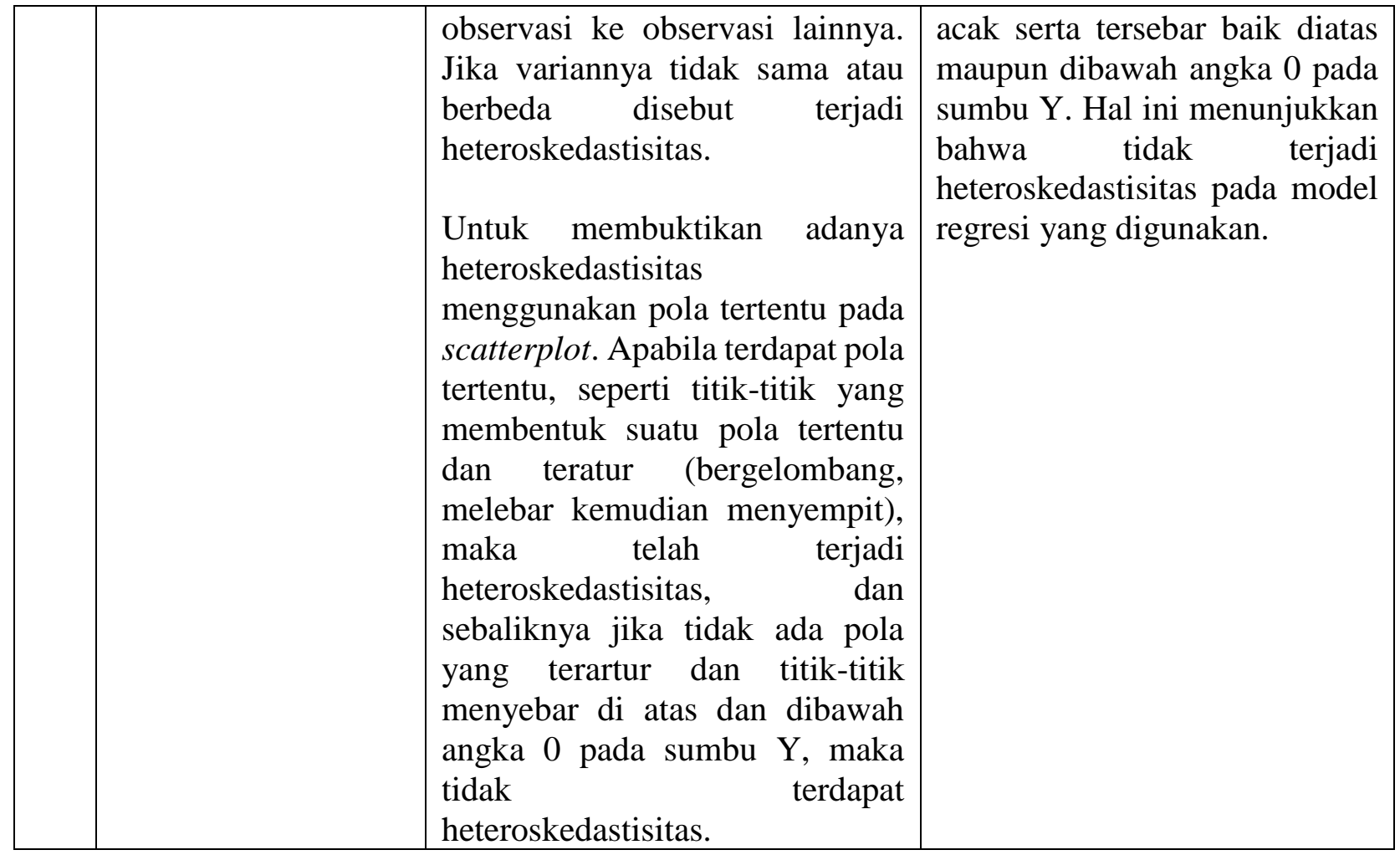

Sumber: Peneliti, diolah.

\section{Model Persamaan Regresi Linier Berganda}

Model persamaan regresi diperoleh dari konstanta dan koefisien korelasi untuk persamaan regresi linier berganda. Persamaan regresi linier berganda dalam penelitian ini adalah:

$\mathrm{Y}=23,447-0,002 \mathrm{X}_{1}+0,004 \mathrm{X}_{2}+25,867 \mathrm{X}_{3}$

Konstanta $=23,447$ menunjukkan besarnya nilai laba bersih (Y) dengan asumsi bahwa variabel lain dianggap nol (cateris paribus). Koefisien regresi untuk variabel pembiayaan mudharabah-musyarakah $\left(\mathrm{X}_{1}\right)=-0,002$ yang berarti setiap adanya peningkatan pada variabel mudharabah-musyarakah $\left(\mathrm{X}_{1}\right)$ sebesar satu satuan, maka akan mengakibatkan laba bersih (Y) turun sebesar -0,002 satuan dengan asumsi variabel lain dianggap nol (cateris paribus). Koefisien regresi untuk variabel pembiayaan $q \operatorname{ardh}\left(\mathrm{X}_{2}\right)=0,004$ yang berarti setiap adanya peningkatan pada variabel pembiayaan qardh $\left(\mathrm{X}_{2}\right)$ sebesar satu satuan maka mengakibatkan laba bersih $(\mathrm{Y})$ naik sebesar 0,004 satuan dengan asumsi variabel lain dianggap nol (cateris paribus). Koefisien regresi untuk variabel zakat $\left(\mathrm{X}_{3}\right)=25,867$ yang berati setiap adanya peningkatan pada variabel zakat $\left(\mathrm{X}_{3}\right)$ sebesar satu satuan, maka akan mengakibatkan laba bersi (Y) naik sebesar 25,867 satuan dengan asumsi variabel lain dianggap nol (cateris paribus).

\section{Analisis Koefisien Determinasi dan Korelasi}

Koefisien determinasi digunakan untuk menghitung besarnya pengaruh atau kontribusi variabel eksogen terhadap variabel endogen. Pada hasil dari penelitian ini meunjukkan bahwa $\mathrm{R}$ Square (koefisien determinasi) adalah sebesar 0,823, yang berarti bahwa pembiayaan mudharabah-musyarakah $\left(\mathrm{X}_{1}\right)$, pembiayaan qardh $\left(\mathrm{X}_{2}\right)$ dan zakat $\left(\mathrm{X}_{3}\right)$ mampu menjelaskan variabilitas dari laba bersih (Y) sebesar $82,3 \%$ dan sisanya sebesar 16,8\% dijelaskan oleh variabel lain yang tidak dibahas pada penelitian ini.

Nilai korelasi dalam penelitian ini menunjukkan bahwa hubungan antara variabel eksogen, yaitu pembiayaan mudharabah-musyarakah $\left(\mathrm{X}_{1}\right)$, pembiayaan qardh $\left(\mathrm{X}_{2}\right)$ dan zakat $\left(\mathrm{X}_{3}\right)$ terhadap variabel laba bersih (Y) memiliki nilai korelasi sangat kuat dan positif yaitu sebesar 0,907.

\section{Uji Hipotesis}

Tabel 6. Hasil Uji Hipotesis

\begin{tabular}{|l|l|l|l} 
No & Uji Hipotesis & Penjelasan & Hasil \\
\hline
\end{tabular}




\begin{tabular}{|c|c|c|c|}
\hline 1 & Uji t & $\begin{array}{l}\text { Hasil uji t dapat digunakan untuk } \\
\text { mengetahui pengaruh variabel } \\
\text { secara parsial terhadap variabel } \\
\text { endogen. Pada uji t, jika t hitung } \\
<\mathrm{t} \text { tabel maka } \mathrm{H}_{0} \text { diterima. } \\
\text { Apabila } \mathrm{H}_{0} \text { diterima maka } \\
\text { variabel eksogen secara parsial } \\
\text { tidak berpengaruh terhadap } \\
\text { variabel endogen. }\end{array}$ & $\begin{array}{l}\mathrm{t} \text { tabel dalam penelitian ini adalah } \\
2,353 \text {. Hasil penelitian menunjukkan } \\
\text { bahwa zakat }\left(\mathrm{X}_{3}\right) \text { memiliki t hitung } \\
7,157 \text {, maka dapat disimpulkan } \\
\text { bahwa zakat }\left(\mathrm{X}_{3}\right) \text { berpengaruh } \\
\text { signifikan secara parsial pada laba } \\
\text { bersih. } \\
\text { Sedangkan variabel pembiayaan } \\
\left.\text { mudharabah-musyarakah ( } \mathrm{X}_{1}\right) \text { dan } \\
\text { pembiayaan qardh }\left(\mathrm{X}_{2}\right) \text { memiliki t } \\
\text { hitung masing-masing -0,66 dan } 0,75 \text {, } \\
\text { makadapat disimpulkan bahwa } \\
\text { pembiayaan mudharabah- } \\
\text { musyarakah dan qardh tidak } \\
\text { berpengaruh secara signifikan } \\
\text { terhadap laba bersih }(\mathrm{Y}) \text {. }\end{array}$ \\
\hline 2 & Uji F & 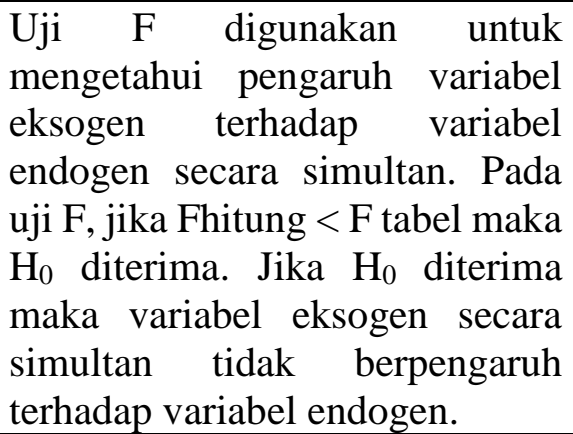 & $\begin{array}{l}\text { F tabel dalam penelitian ini adalah } \\
3,43 \text {. Hasil penelitian menunjukkan } \\
\text { nilai } F \text { hitung adalah } 32,565 \text {. Lebih } \\
\text { besar dibandingkan dengan F tabel. } \\
\text { Hal ini menunjukkan bahwa secara } \\
\text { simultan variabel eksogen } \\
\text { berpengaruh signifikan terhadap laba } \\
\text { bersih. }\end{array}$ \\
\hline
\end{tabular}

Sumber: Peneliti, diolah.

\section{Pembahasan}

Berdasarkan hasil uji t dapat diketahui bahwa pembiayaan mudharabah-musyarakah tidak signifikan terhadap laba bersih, hal ini disebabkan karena t hit $(-0,66)<\mathrm{t}$ tab $(2,352)$. Jadi, semakin meningkatnya pembiayaan mudharabah-musyarakah yang disalurkan oleh perbankan syariah akan menurunkan laba bersih perbankan syariah. Pada tabel menunjukkan bahwa penyaluran pembiayaan mudharabah-musyarakah pada perbankan syariah hampir secara keseluruan mengalami kenaikan selama periode 2010-2014 namun belum optimal karena tingkat pengembalian pembiayaan mudharabah-musyarakah menyebabkan penurunan laba perbankan syariah.

Berdasarkan hasil uji t dapat diketahui bahwa pembiayaan qardh tidak signifikan terhadap laba bersih, hal ini disebabkan karena $t$ hit $(0,75)<\mathrm{t}$ tab $(2,352)$. Jadi, semakin meningkatnya pembiayaan qardh yang disalurkan oleh perbankan syariah akan menurunkan laba bersih perbankan syariah. Hal ini disebabkan karena nasabah pembiayaan qardh hanya mengembalikan sejumlah pokok pinjaman dan tidak ada biaya tambahan yang diperjanjikan kecuali biaya administrasi dan biaya sewa tempat jaminan.

Berdasarkan hasil uji t dapat diketahui bahwa zakat positif signifikan terhadap laba bersih, hal ini disebabkan karena $t$ hit $(7,157)>t$ tab $(2,352)$. Jadi, semakin meningkatnya zakat yang dikeluarkan oleh perbankan syariah akan menaikkan laba bersih perbankan syariah. Hal ini sesuai dengan Al-Qur'an Al-Baqarah 261 bahwa dengan mengeluarkan zakat, maka Allah SWT akan melipatgandakan harta yang kita punya.

Berdasarkan hasil uji $\mathrm{F}$, dapat diketahui bahwa pembiayaan mudharabah-musyarakah, pembiayaan qardh dan zakat secara simultan menghasilkan positif signifikan dengan $\mathrm{F}$ tabel dalam penelitian ini adalah 3,43dan nilai $F$ hitung adalah 32,565. Maka, $F$ hitung lebih besar 
dibandingkan dengan $\mathrm{F}$ tabel. Hal ini berarti bahwa pembiayaan mudharabah-musyarakah, pembiayaan qardh dan zakat memiliki pengaruh terhadap profitabilitas, yaitu laba bersih.

\section{Kesimpulan}

Berdasarkan hasil analisis dan pengujian hipotesis, maka dapat diambil kesimpulan sebagai berikut:

1. Kinerja sosial berupa pembiayaan mudharabah-musyarakah $\left(\mathrm{X}_{1}\right)$ tidak berpengaruh signifikan terhadap laba bersih dengan persamaan $\mathrm{Y}=23,447-0,002 \mathrm{X}_{1}$. Hal ini menunjukkan bahwa setiap kenaikan satu satuan pembiayaan mudharabah-musyarakah maka akan terjadi perubahan sebesar -0,002 pada laba bersih. Pembiayaan mudharabahmusyarakah pada perbankan syariah hampir secara keseluruan mengalami kenaikan selama periode 2010-2014 namun belum optimal karena tingkat pengembalian pembiayaan mudharabah-musyarakah menyebabkan penurunan laba perbankan syariah.

2. Kinerja sosial berupa pembiayaan qardh $\left(\mathrm{X}_{2}\right)$ tidak berpengaruh signifikan terhadap laba bersih dengan persamaan $\mathrm{Y}=23,447+0,004 \mathrm{X}_{2}$. Hal ini menunjukkan bahwa setiap kenaikan satu satuan pembiayaan qardh maka akan terjadi perubahan sebesar 0,004 pada laba bersih. Hal ini disebabkan karena nasabah pembiayaan qardh hanya mengembalikan sejumlah pokok pinjaman dan tidak ada biaya tambahan yang diperjanjikan kecuali biaya administrasi dan biaya sewa tempat jaminan.

3. Kinerja sosial berupa zakat $\left(\mathrm{X}_{3}\right)$ berpengaruh positif signifikan terhadap laba bersih dengan persamaan $\mathrm{Y}=23,447+25,867 \mathrm{X}_{3}$. Hal ini menunjukkan bahwa setiap kenaikan satu satuan pengeluaran zakat maka akan terjadi perubahan sebesar 25,867 pada laba bersih. Hal ini sesuai dengan Al-Qur'an Al-Baqarah 261 bahwa dengan mengeluarkan zakat, maka Allah SWT akan melipatgandakan harta yang kita punya.

Kinerja sosial yang berupa pembiayaan mudharabah-musyarakah, pembiayaan qardh dan zakat secara simultan berpengaruh positif signifikan terhadap laba bersih.

\section{Daftar Pustaka}

Anshori, Muslich \& Sri Iswati. (2009). Metodologi Penelitian Kuantitatif. Surabaya: Pusat Penerbitan dan Percetakan Unair (AUP)

Antonio, Syafi'i. (2001). Bank Syariah: Dari Teori ke Praktik. Depok: Gema Insani dan Tazkia Cendikia.

Anshori, Muslich \& Sri Iswati. (2009). Metodologi Penelitian Kuantitatif. Surabaya: Pusat Penerbitan dan Percetakan Unair (AUP)

Amalia dan Wijayanto. (2007). Pengaruh Environmental Performance dan Envoironmental Disclosure terhadap Economic Performance. Proceedings The 1st Accounting Conference. Depok.

Astuti, Dewi. (2004). Manajemen Keuangan Perusahaan. Jakarta: Ghalia Indonesia.

Kurniawan. (2010). Pengaruh Qardh terhadap Performa Bank Syariah Periode 2005:2-2008:12. Skripsi tidak diterbitkan. Fakultas Ekonomi dan Bisnis Universitas Airlangga Surabaya.

Puspasari, Rosana. (2014). Pengaruh Kinerja Sosial terhadap Profitabilitas Bank Syariah. Jurnal Ekonomi Syariah, Teori dan Terapan. Universitas Airlangga.

Rivai dan Arifin. (2010). Islamic Banking. Jakarta: Bumi Aksara.

Ryandono, Muhammad. (2010). Peran dan Pengaruh Penghimpunan Dana dan Penyaluran Dana serta Kinerja Bank terhadap Kesejahteraan Karyawan Bank Islam Perspektif Maqashid Syariah di Indonesia. Disertasi tidak diterbitkan. Sekolah Pascasarjana Universitas Airlangga Surabaya.

Setiawan. (2009). Kesehatan Financial dan Kinerja Sosial Bank Umum Syariah di Indonesia. Makalah disajikan pada seminar ilmiah kerjasama Magister Bisnis Keuangan Islam Universitas Paramadina, Ikatan Ahli Ekonomi Islam (IAIE) Pusat dan Masyarakat Ekonomi Islam. 
Suharto, dkk. (2003). Konsep, Produk dan Implementasi Operasional Bank Syariah. Jakarta: Djambatan.

Sugiono. (2012). Metode Penelitian Kuantitati, Kualitatif dan R\&D. Cetakan ke-17. Bandung: CV. Alfabeta.

Undang-Undang Republik Indonesia Nomor 21 tentang Perbankan Syariah. 